\title{
A duodenal role in gastrin release
}

\author{
J. R. HAYES, ${ }^{1}$ JOY ARDILL, T. L. KENNEDY, AND K. D. BUCHANAN \\ From the Departments of Medicine and Surgery, The Queen's University of Belfast
}

SUMMARY Observations on the plasma gastrin response to feeding protein in patients with the dumping syndrome, patients with pyloric stenosis, and patients asymptomatic after gastric surgery suggested that the duodenum might be important in the mechanism of gastrin release. This duodenal role was confirmed by the finding that when the stimulus was placed directly in the duodenum peak gastrin levels occurred earlier than when the stimulus was placed directly in the stomach.

Gastrin was first isolated from the antrum of the stomach (Edkins, 1905) and it has been shown in dogs that chemical and mechanical stimulation of the antrum will result in gastrin release (Grossman, Robertson, and Ivy, 1948; Woodward, Lyon, Landor, and Dragstedt, 1954). During investigations on the effect of feeding protein on gastrin release, certain observations suggested that in man the presence of food in the duodenum was of importance in the mechanism of release of the hormone. We should like to present these observations and the results of an experiment which they prompted.

\section{Methods}

Twenty patients with duodenal ulceration, subsequently confirmed at operation, were studied. Five of these patients had pyloric stenosis. We also studied 15 patients at least three months after surgery for chronic duodenal ulcer. Five of this group were asymptomatic following selective vagotomy and pyloroplasty, five had no symptoms following selective vagotomy and gastrojejunostomy, and five had symptoms of the dumping syndrome following selective vagotomy and pyloroplasty. In those patients with gastrojejunostomy, the stoma was placed as close as possible to the pylorus, resulting in duodenal but not antral bypass.

After an overnight fast patients were given a standard meal of cooked minced beef $(25 \mathrm{~g}$ protein in $150 \mathrm{ml}$ ). Peripheral venous samples for gastrin estimation were taken at $-15,0,15,30,45,60,90$, and 120 minutes. Measurements of basal and penta-

\footnotetext{
${ }^{1}$ Present address: Division of Endocrinology and Metabolism, Department of Medicine, University of Washington, Seattle 98105 USA.

Received for publication 9 May 1974.
}

gastrin-stimulated acid secretion were performed on duodenal ulcer patients on a separate occasion. One normal subject was studied following the intraduodenal and intragastric instillation of meat extract (Oxo). After an overnight fast, a tube was placed in the duodenum under radiographic control and 200 $\mathrm{ml}$ of meat extract given through the tube over three minutes. Blood samples were taken at $-15,0,5,10$, 15,30 , and 45 minutes. On another occasion the experiment was repeated with the tube placed in the stomach. Each experiment was repeated three times.

Gastrin levels were measured by radioimmunoassay (Ardill, 1973). The assay uses antibody raised in rabbits against synthetic human gastrin I and the standards used are supplied by the Medical Research Council (gastrin human type synthetic 68/439). The sensitivity of the assay is $10-15 \mathrm{pg} / \mathrm{ml}$. Some cross reactivity with cholecystokinin-pancreozymin does exist but greater than 10000 times the concentration of this material is required to produce a similar fall in bound counts as standard gastrin, and we know from preliminary chromatographic studies that the antiserum recognizes not only the heptadecapeptide but also big gastrin.

All samples from each experiment were assayed in the same batch and each sample was assayed in triplicate.

\section{Results}

The mean gastrin levels in patients with uncomplicated duodenal ulceration, with pyloric stenosis, and with the dumping syndrome are shown in figure 1. We have found gastrin levels to show a log normal distribution, therefore statistical analysis was performed using logarithmic values. Analysis of variance shows that in patients with uncomplicated duodenal ulceration gastrin levels at $15,30,45$, and 60 minutes 


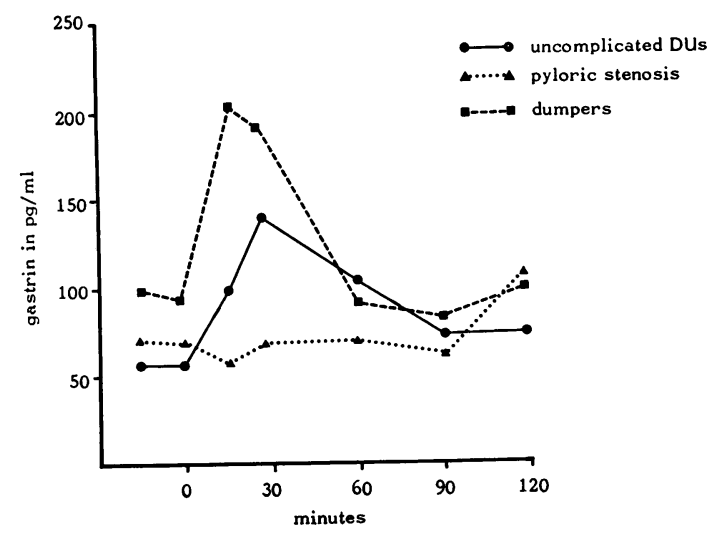

Fig 1 Gastrin levels following protein in uncomplicated duodenal ulcer patients, duodenal ulcer patients with pyloric stenosis, and patients with the dumping syndrome

were significantly greater than the fasting level ( $\mathrm{P}<0.05, \mathrm{P}<0.005, \mathrm{P}<0.005, \mathrm{P}<0.005$ respectively). The peak level occurred in the 30-minute sample. In patients with the dumping syndrome gastrin levels at 15,30 , and 45 minutes were significantly greater than the fasting level $(P<0.005$, $\mathrm{P}<0.005, \mathrm{P}<0.005$ respectively). The peak level occurred in the 15-minute sample. In none of the patients with uncomplicated duodenal ulceration did the highest gastrin level occur at 15 minutes. A different pattern of gastrin release was seen in patients with pyloric stenosis. No gastrin level during the test differed significantly from the fasting level. In one patient (table I) a normal pattern of gastrin release was seen. However, the gastrin level only began to rise in the 45-minute sample and the peak level occurred at 60 minutes. Basal acid secretion in patients with pyloric stenosis, $10 \pm 5 \mathrm{~m}$-equiv/h (mean $\pm \mathrm{SEM})$ was significantly greater $(\mathrm{P}<0.05)$ than the basal acid secretion in patients with uncomplicated duodenal ulceration, $4.6 \pm 1.4 \mathrm{~m}$-equiv/h (mean \pm SEM). Stimulated acid secretion in patients with pyloric stenosis, $43 \pm 5.6$ m-equiv/h (mean \pm SEM) was also significantly greater $(P<0.05)$ than in patients with uncomplicated duodenal ulcer which was $32 \pm 3 \mathrm{~m}$-equiv/h.

The gastrin levels following protein in patients with selective vagotomy and pyloroplasty and in patients with selective vagotomy and gastrojejunostomy are shown in table II. After pyloroplasty analysis of variance shows gastrin levels at 15, 30, and 45 minutes to be significantly greater than the fasting level $(\mathrm{P}<0.05, \mathrm{P}<0.005, \mathrm{P}<0.01$ respectively). After gastrojejunostomy no gastrin level during the test was significantly greater than the

\begin{tabular}{lllllllll}
\hline Patient & \multicolumn{7}{l}{ Gastrin Levels $(\mathrm{pg} / \mathrm{ml})$ after Protein Meal at Stated Intervals (minutes) } \\
\cline { 2 - 10 } & -15 & 0 & 15 & 30 & 45 & 60 & 90 & 120 \\
\hline J.H. & 120 & 110 & 110 & 110 & 180 & 240 & 140 & 80 \\
S.R. & 90 & 90 & 80 & 105 & 115 & 110 & 115 & 140 \\
A.W. & 100 & 80 & 110 & 100 & 90 & 110 & 100 & 135 \\
J.C. & 20 & 30 & 20 & 30 & 15 & 10 & 10 & 20 \\
T.S. & 95 & 95 & 95 & 105 & 75 & 75 & 95 & 105 \\
Mean + SEM & $72+28$ & $74+19$ & $62+30$ & $76+24$ & $83+35$ & $79+50$ & $69+39$ & $117+70$ \\
\hline
\end{tabular}

Table I Gastrin levels following protein in patients with pyloric stenosis

\begin{tabular}{|c|c|c|c|c|c|c|c|c|}
\hline \multirow[t]{2}{*}{ Operation } & \multicolumn{8}{|c|}{ Gastrin Levels after Protein Meals (pg/ml) at Stated Intervals (minutes) } \\
\hline & -15 & 0 & 15 & 30 & 45 & 60 & 90 & 120 \\
\hline $\begin{array}{l}\text { Selective vagotomy and } \\
\text { gastrojejunostomy }\end{array}$ & $\begin{array}{r}130 \\
280 \\
15 \\
95 \\
120\end{array}$ & $\begin{array}{r}130 \\
250 \\
10 \\
95 \\
120\end{array}$ & $\begin{array}{r}230 \\
255 \\
20 \\
165 \\
295\end{array}$ & $\begin{array}{r}230 \\
240 \\
10 \\
250 \\
265\end{array}$ & $\begin{array}{r}180 \\
180 \\
10 \\
165 \\
95\end{array}$ & $\begin{array}{r}130 \\
150 \\
15 \\
125 \\
125\end{array}$ & $\begin{array}{r}120 \\
195 \\
10 \\
105 \\
70\end{array}$ & $\begin{array}{r}175 \\
180 \\
10 \\
80 \\
115\end{array}$ \\
\hline Mean & 83 & 76 & 138 & 129 & 87 & 85 & 74 & 75 \\
\hline
\end{tabular}

Table II Gastrin levels following protein in patients after pyloroplasty and after gastrojejunostomy 


\begin{tabular}{|c|c|c|c|c|c|c|c|}
\hline & \multicolumn{7}{|c|}{ Gastrin Levels after Meat Extract $(\mathrm{pg} / \mathrm{ml})$ at Stated Intervals (minutes) } \\
\hline & -15 & 0 & 5 & 10 & 13 & 30 & 45 \\
\hline Intragastric & $\begin{array}{l}35 \\
40 \\
40\end{array}$ & $\begin{array}{l}35 \\
50 \\
40\end{array}$ & $\begin{array}{l}30 \\
50 \\
60\end{array}$ & $\begin{array}{l}25 \\
80 \\
70\end{array}$ & $\begin{array}{l}30 \\
80 \\
80\end{array}$ & $\begin{array}{l}50 \\
75 \\
90\end{array}$ & $\begin{array}{l}50 \\
75 \\
60\end{array}$ \\
\hline Intraduodenal & $\begin{array}{l}30 \\
40 \\
30\end{array}$ & $\begin{array}{l}30 \\
30 \\
20\end{array}$ & $\begin{array}{l}60 \\
70 \\
35\end{array}$ & $\begin{array}{l}50 \\
80 \\
60\end{array}$ & $\begin{array}{l}60 \\
80 \\
60\end{array}$ & $\begin{array}{l}60 \\
60 \\
20\end{array}$ & $\begin{array}{l}40 \\
30 \\
15\end{array}$ \\
\hline
\end{tabular}

Table III Gastrin levels following intragastric and intraduodenal meat extract

fasting level. A measure of the gastrin output may be obtained from the area under the curve. The gastrin output following pyloroplasty was $178 \pm 13$ (mean \pm SEM) and was significantly greater $(P<0.005)$ than the gastrin output following gastrojejunostomy which was $115 \pm 11$ (mean \pm SEM) (fig 2).

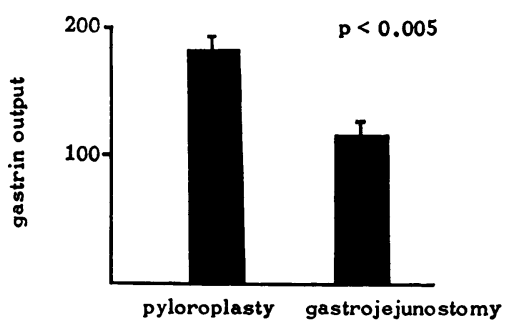

Fig 2 Gastrin output following protein in patients with pyloroplasty and in patients with gastrojejunostomy

The gastrin levels following intragastric and intraduodenal instillation of meat extract are recorded in table III and the mean \% increase in fasting gastrin shown in figure 3. With intraduodenal administration the peak gastrin level is found in the 15-minute sample while with intragastric administration peak levels occurred at 30 minutes.

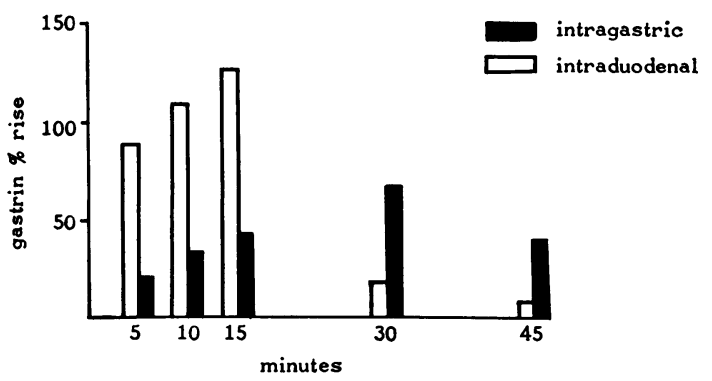

Fig 3 Percentage rise in gastrin levels after intraduodenal and intragastric instillation of meat extract

\section{Discussion}

In duodenal ulcer patients without pyloric obstruction the gastrin response to protein, with the peak occurring at $30-45$ minutes, is similar to that described by Korman, Soveny, and Hansky (1971). In patients with the dumping syndrome and presumed rapid gastric emptying peak levels occurred in the 15-minute sample, thus suggesting that for gastrin levels to rise it is necessary for food to pass into the duodenum. This concept would also explain the pattern of release found in patients with pyloric stenosis although alternative explanations are possible. Gastrin release may have been inhibited by the excessive acid secretion found in these patients or it is possible that the stasis resulting from the pyloric obstruction produced severe antral gastritis with destruction of $G$ cells. Nevertheless the fact that one patient had a relatively normal pattern of gastrin release, but with a peak value in the 60-minute samples 30 minutes after the peak level found in patients without pyloric obstruction, strengthens the concept of a duodenal role in the mechanism of gastrin release.

Comparison of the gastrin responses in patients with pyloroplasty and in patients with gastrojejunostomy showed that the gastrin response when protein entered the duodenum directly was significantly greater than when it was possible for food to bypass the duodenum. In all cases the gastrojejunostomy was placed as close as possible to the pylorus, resulting in the possibility of duodenal but not of antral bypass. Retzer, Morrison, and Harrison (1960) showed a $36 \%$ fall in Heidenhain pouch secretion following antral gastroenterostomy and our findings are similar to those of Stern and Walsh (1972) who studied patients following Billroth I and Billroth II gastrectomies. Further evidence of the importance of the duodenum is provided by the timing of the gastrin peak following intraduodenal as opposed to intragastric meat extract.

It is of interest that in six out of eight patients studied by Walsh, Yalow, and Berson (1971) the administration of atropine delayed the peak gastrin 
response to feeding, and Korman et al (1971) found that atropine delayed the peak gastrin response to food by 30 minutes. The evidence of the present study would suggest that this delay resulted from impaired gastric emptying following atropine.

Immunoreactive gastrin is known to exist in at least two molecular fractions and the relative concentration of big gastrin is greater in the duodenum than in the stomach (Berson and Yalow, 1971). Thus it is possible that the antiserum used in our assay recognizes selectively gastrin of duodenal origin. We know, however, that both big gastrin and the heptadecapeptide cross react in the assay, and we have confirmed the observations of McGuigan and Trudeau (1972) who showed that the major portion of the gastrin released in response to feeding is antral in origin (Hennessy and Hayes, 1973).

In the studies reported in the present paper the protein stimulus was of small volume and thus unlikely to provoke significant distension of the stomach. Our observations suggest that in the mechanism of the gastrin response to protein stimulation the duodenum may have a more important role than has hitherto been suggested.
Dr J. R. Hayes is in receipt of a research fellowship from the Royal Victoria Hospital.

\section{References}

Ardill, J. (1973). PhD Thesis. The Queen's University of Belfast.

Berson, S. A., and Yalow, R. S. (1971). Nature of immunoreactive gastrin extracted from tissues of gastrointestinal tract. Gastroenterology, 602, 215-222.

Edkins, J. S. (1905). On the chemical mechanism of gastric secretion. Proc. roy. Soc. B., 76, 376.

Grossman, M. I., Robertson, C. R., and Ivy, A. C. (1948). Proof of a hormonal mechanism for gastric secretion: the humoral transmission of the distention stimulus. Amer. J. Physiol., 153, 1-9.

Hennessy, T. P. J., and Hayes, J. R. (1973). In preparation for publication.

Korman, M. G., Soveny, C., and Hansky, J. (1971). Serum gastrin in duodenal ulcer: I Basal levels and effect of food and atropine. Gut, 12, 899-902.

McGuigan, J. E., and Trudeau, W. L. (1972). Serum gastrin levels before and after vagotomy and pyloroplasty or vagotomy and antrectomy. New Engl. J. Med., 286, 184-188.

Retzer, O., Morrison, M., and Harrison, R. C. (1960). The effect of gastroenterostomy on gastric secretion. Surg. Gynec. Obstet. 111, 285-288.

Stern, D. H., and Walsh, J. H. (1972). Release of gastrin in post operative duodenal ulcer patients. Gastroenterology, 62, 817.

Walsh, J. H., Yalow, R. S., and Berson, S. A. (1971). The effect of atropine on plasma gastrin response to feeding. Gastroenterology, 60, 16-21.

Woodward, E. R., Lyon, E. S., Landor, J., and Dragstedt, L. R. (1954). The physiology of the gastric antrum; experimental studies on isolated antral pouches in dogs. Gastroenterology, 27, 766-785. 